\title{
PENERAPAN TEKNOLOGI UNTUK MENGONTROL SUHU DAN KELEMBABAN PADA BUDIDAYA AYAM JENIS PETELOR
}

\author{
Firman Nurdiansyah $^{1 *}$, Aviv Yuniar Rahman ${ }^{2}$ \\ 1,2 Program Studi Teknik Informatika, Fakultas Teknik, Universitas Widyagama Malang \\ *Email Korespondensi : firmannurdiyansyah7@gmail.com
}

\begin{abstract}
ABSTRAK
Kegiatan pengabdian kepada masyarakat dengan khalayak sasaran peternak ayam jenis petelor di Kecamatan Wagir Kabupaten Malang. Kegiatan ini bertujuan untuk memberikan pelatihan dan pendampingan dalam upaya meningkatkan pengetahuan dan kemampuan SDM mengukur suhu dan kelembaban yang efektif dan efisien. Permasalahan yang dihadapi oleh mitra adalah produksi yang masih rendah. Hal tersebut salah satunya terjadi karena pengontrolan kelembapan dan suhu yang masih manual. Pengontrolan manual tersebut menyebabkan perkembangan embrio kurang baik dan bahkan meningkatkan kematian embrional ayam, sehingga daya produksi rendah. Pendekatan penyelesaian masalah dilakukan dengan tiga tahapan yaitu survey, pelatihan dan pendampingan, serta evaluasi. Luaran yang diharapkan dari kegiatan ini adalah publikasi nasional dan draf buku. Hasil yang dicapai mitra antara lain; 1) Peningkatan kesejahteraan mitra melalui pengeturan suhu dan kelembaban kandang sehingga memaksimalkan produksi telor ayam; 2)Program pendampingan dan pelatihan untuk pengukuran suhu dan kelembaban. 3)Memberikan kemampuan kepada peternak telor (mitra) bagaimana cara monitoring suhu dan kelembaban. 4)Memberikan pengetahuan mengenai pentingnya pengaruh suhu dan kelembapan terhadap peternakan ayam petelor; 5)Memberikan keterampilan kepada peternak telor (mitra) mengenai cara menggunakan aplikasi pengukuran suhu dan kelembaban dengan smartphone; 6)Mengurangi resiko kematian terhadap ayam petelor.
\end{abstract}

Kata kunci: Budidaya Ayam, Suhu, Kelembaban

\section{ABSTRACT}

Community service activities with the target audience of breeders of type chicken in District Wagir Malang Regency. This activity aims to provide training and assistance to increase the knowledge and ability of human resources to measure temperature and humidity effectively and efficiently. The problem faced by partners is that production is still low. Manual control causes the development of embryos is not proper and even increases the embryonal death of chickens, resulting in low production power. The problem-solving approach is carried out in three stages namely survey, training and assistance, and evaluation. Expected outputs from this activity are national publications and book drafts. The results achieved by partners include; 1) Increasing the welfare of partners through setting the temperature and humidity of the cage to maximise the production of chicken eggs; 2) Mentoring and training programs for temperature and humidity measurement. 3) Provides the ability to egg farmers (partners) how to monitor temperature and humidity. 4) Provide knowledge about the importance of the influence of temperature and humidity on laying hens; 5) Providing skills to egg farmers (partners) on how to use temperature and humidity measurement applications with smartphones; 6) Reducing the risk of death of laying hens.

Keywords: Chicken Culture, Temperature, Humidity

\section{PENDAHULUAN}

Dewasa ini, dunia industri perunggasan memiliki peran penting sebagai pemasok kebutuhan protein hewani dalam negeri (Fanani, et al., 2019). Dan disamping itu perannya dapat menumbuhkan potensi peluan kerja pada masyarakat kita (Fitriyani \& Widyaningsih, 2017). Industri perunggasan sangat memiliki peran penting dalam penyediaan protein hewani pada masyarakat indonesia (Fitriyani \& Widyaningsih, 2017), karena dimasa sekarang kesadarang masyarakat sudah tinggi (Mappanganro, Syam \& Ali, 2018) tentang kebutuhan protein untuk kesahatan tubuh (Ramdani, 2019). Maka potensi terbesar dari peternakan ayam 
yang ada adalah dari peternakan ayam ras petelur. Kebutuhan masyar/akat akan protein hewani khususnya telur dari tahun ketahun semakin meningkat (Damayanti, 2019). Bisa dilihat dari beberapa suvey yang sudah dilakukan dimana. Peternakan ayam ras petelur sendiri sudah banyak dilakukan dibeberapa daerah di Indonesia (Pakaya, Zainudin \& Dako, 2019). Dalam prosesnya, beternak ayam ras petelur sendiri memiliki beberapa kendala yang mana bisa berdampak dalam produktifitas telus yang dihasilkan. Salah satu contohnya adalah kematian ayam. Hal ini sebenarnya memiliki beberapa faktor, mulai dari kondisi ayam yang strees, pencemaran udara, dan terjangkitnya virus unggas. Penelitian yang kami lakukan sendiri fokus ke dampak suhu dan kelembaban di area kandang pada kesehatan ayam ras petelor itu sendiri(Prastiyo, Hartono \& Margianto, 2018).

\section{METODE}

Metode pelaksanaan yang dilakukan secara struktural kegiatan detail bisa dilihat pada Gambar 1.

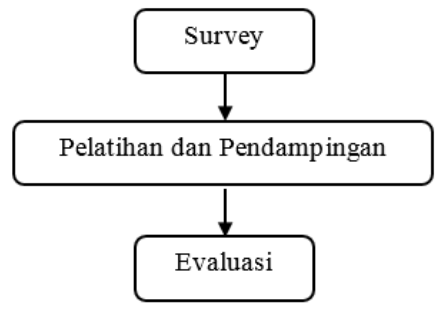

Gambar 1. Metode Pelaksanaan

\section{a. Survey}

Pada tahap ini kami mencoba mensurvey juga dari jenis pakan dan zat minuman yang diberikan, karena itu juga salah satu faktor dalam baik tidaknya kesehatan unggas ayam tersebut. Dan dalam pengukuran suhu serta kelembaban sendiri dilakukan pada hari yang sama di 2 tempat yang berbeda. Lokasi pertama dilakukan di Desa Bakalan, Kec. Bululawang, Kab.Malang dan lokasi kedua di Kec. Wagir, Kab. Malang.

\section{b. Pelatihan dan Pendampingan}

Pelatihan dan pendampingan untuk mengukur suhu dan kelembaban kita pakai karena secara umum ini berpengaruh besar pada kelangsungan hidup unggas, dalam hal ini ayam petelor. Karena kita ketahui daerah ayam ini sendiri memiliki kerentanan terhadap suhu dan kelembapan, jadi kita terlalu dingin atau terlalu panas bisa mengakibatkan kematian pada unggas tersebut. Maka diharapkan dengan hasil pengukuran ini dapat membantu para peternak untuk mengkondisikan area kandang peternakan dari sisi suhu dan kelembaban guna menjaga keberlangsungan hidup ayam ras petelor.

\section{c. Evaluasi}

Tahap ini dilakukan setelah mengukur suhu dan kelembaban. Evaluasi ini dilakukan untuk melihat pengaruh suhu dan kelembaban terhadap produktivitas ayam jenis petelor. Setelah dilakukan evaluasi dan mengetahui kondisi suhu dan kelembaban yang cocok maka perlu dilakukan pengontrolan setiap harinya.

\section{HASIL DAN PEMBAHASAN}

Tahap survey dimulai dari yang pertama yaitu berkomunikasi dengan penanggung jawab. Dalam hal ini komunikasi antara penanggung jawab mitra maupun peneliti sangat penting dilakukan. Serta dalam hal ini juga membuat peneliti dapat berkordinasi dengan baik tentang pengamatan yang akan dilakukan. 


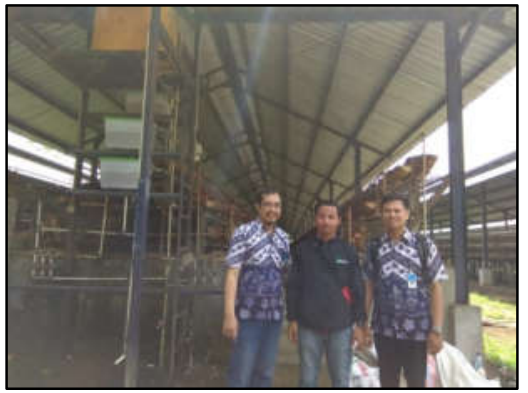

Gambar 2. Komunikasi dengan Mitra 1

Selanjutnya yaitu melihat kondisi kandang, dalam hal ini peneliti membuat survei ke lapangan melihat situasi dan kondisi kandang untuk dijadikan sebuah data. Tahap selanjutnya yaitu mengecek pakan dan minum unggas. Kemudian pengecekkan pakan dan minum unggas, dimana dalam hal ini sangat penting guna untuk dijadikan bahan laporan sebuah data, Serta dalam tahap berikutnya yaitu survei suhu dan kelembapan kandang yang terdapat di tempat mitra 1, dalam hal ini mengecek sebuah suhu dan kelembapan guna untuk mengetahui posisi steril yang terdapat di dalam kandang. Pada tahap terakhir yaitu menginformasikan hasil survey dan pengecekan kepada penjaga kandang maupun peternak. Dengan struktur tersebut bisa di gambarkan setiap proses mulai dari Gambar 2.

\section{A. Mitra 1}

1. Berkomunikasi dengan Penanggung Jawab

Dalam Gambar 2 merupakan komunikasi antara Mitra dan penanggung jawab kandang peternakan. Dimana dalam hal ini yaitu menjalin komunikasi satu sama lain yang nantinya akan menjadi sebuah kerja sama sebuah penelitian mulai dari awal sampai akhir dalam sebuah penelitian.

2. Melihat Kondisi Kandang

Gambar 3 dmerupakan proses peneliti melihat kondisi kandang setelah berkomunikasi banyak mengenai peternak ayam dengan mitra, peneliti melihat kondisi dari kandang ayam boiler yang terletak di Desa Bangkalan, Kecamatan Bululawang.

3. Survei Air Minum Ayam Boiler Gambar 4. Merupakan survey kandang dan pengecekan yang telah dilakukan peneliti. Survey mengenai zat atau kandungan serta manfaat yang terdapat pada air minum ayam boiler serta melakukan pengecekan kadar kelembapan dan suhu pada kandang.

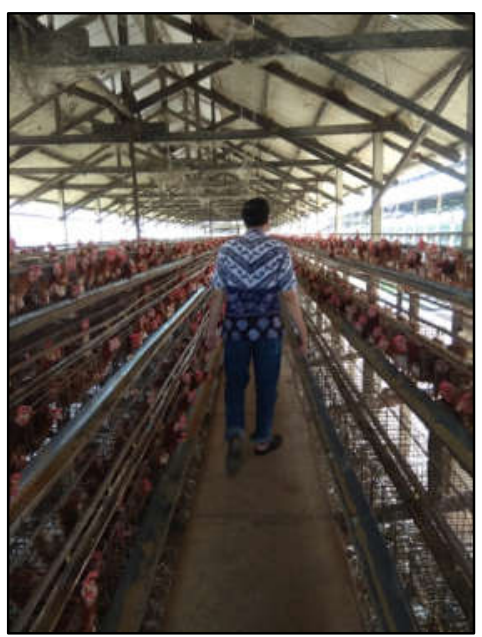

Gambar 3. Melihat kondisi kandang Mitra 1 


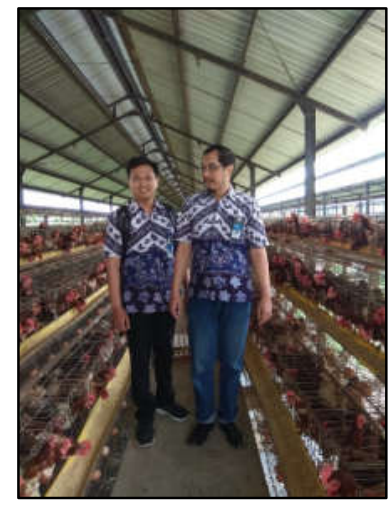

Gambar 4. Survey Kandang Dan Pengecekan

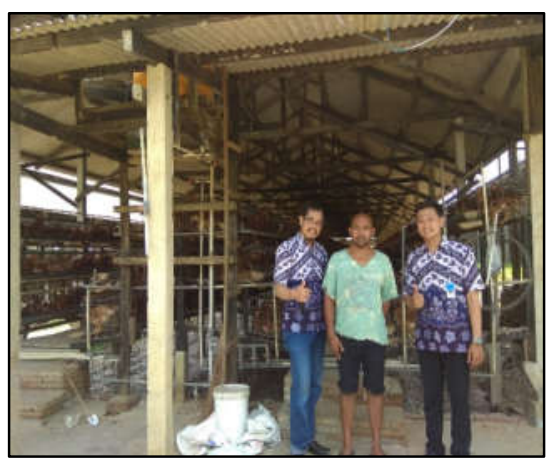

Gambar 5. Komunikasi dengan Mitra 2

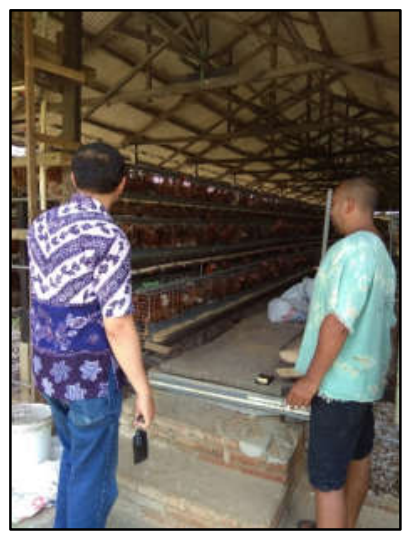

Gambar 6. Survei kandang dan pengecekan Mitra 2

\section{B. Mitra 2}

1. Berkomunikasi dengan Penanggung Jawab

Pada Gambar 5 merupakan proses yang sama pada mitra 1, dalam proses ini juga melakukan komunikasi terlebih dahulu dengan penanggung jawab kandang mengenai bagaimana peternakan ayam boiler di Kecamatan Wagir, Kabupaten Malang. Dalam pengecekan suhu, disana mempunyai suhu sekitar $32^{\circ} \mathrm{C} / 20^{\circ} \mathrm{C}$ dan mmpunyai kelembapan $68 \%$, uuntuk curah hujan disana kira-kira $80 \%$ dan mempunyai kecepatan angin $10 \mathrm{~km} / \mathrm{h}$. Di dalam kandang terdapat jumlah ayam sekitar 12.000 Untuk makanan dari ayam broiler petelur diberikan kosentrat dan minuman dari sumur bor. 


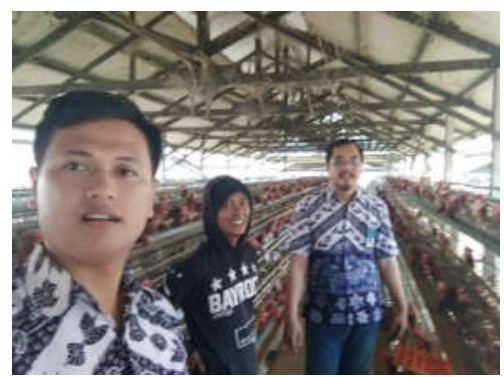

Gambar 7. Komunikasi dengan Mitra 2

Tabel 1. Hasil Pengamatan Kepada Mitra

\begin{tabular}{|l|l|l|}
\hline \multicolumn{1}{|c|}{ Keterangan } & \multicolumn{1}{c|}{ Mitra 1 } & \multicolumn{1}{c|}{ Mitra 2 } \\
\hline Nama & Suyit & Supriyanto \\
\hline Alamat & $\begin{array}{l}\text { Desa Bakalan, Kec. Bululawang, } \\
\text { Kab.Malang }\end{array}$ & Kec. Wagir, Kab. Malang \\
\hline Peternakan & Ayam Broiler Petelur & Ayam Broiler Petelur \\
\hline Jumlah Ayam & 24.000 & 12.000 \\
\hline Produksi Telur & 8 Kw/hari & 4 Kw/hari \\
\hline Umur Ayam & 70 Minggu & 106 Minggu \\
\hline Makanan & Kosentrat & Kosentrat \\
\hline Minum & Sumur bor & Sumur bor \\
\hline SDM & 6 Orang & 3 Orang \\
\hline Jumlah Ayam Mati & $2-3 /$ hari & $2-3 /$ hari \\
\hline Tanggal Pengukuran & 20 November 2019 & $20 \mathrm{November} 2019$ \\
\hline Suhu & $32^{\circ} \mathrm{C} / 21^{\circ} \mathrm{C}$ & $32^{\circ} \mathrm{C} / 20^{\circ} \mathrm{C}$ \\
\hline Curah Hujan & $80^{\circ}$ & $80 \%$ \\
\hline Kecepatan Angin & $12 \mathrm{~km} / \mathrm{h}$ & $10 \mathrm{~km} / \mathrm{h}$ \\
\hline Kelembabapan & $66^{\%}$ & $68 \%$ \\
\hline $\begin{array}{l}\text { Pengaruh Suhu dan } \\
\text { Kelembapan }\end{array}$ & $\begin{array}{l}\text { Ada, jumlah ayam meninggal dan } \\
\text { produksi telur menurun }\end{array}$ & $\begin{array}{l}\text { Ada, jumlah ayam meninggal } \\
\text { dan produksi telur menurun }\end{array}$ \\
\hline
\end{tabular}

2. Survei kandang

Pada gambar 6 merupakan proses yang dilakukan setelah berkomunikasi dengan penanggung jawab kandang, melakukan survey kandang dan melihat suhu dalam kandang dengan menggunakan alat pengukur suhu.

3. Komunikasi dengan petugas kandang

Setelah melakukan survei, kami berkomunikasi dengan petugas kandang mengenai ternak yang ayam boiler.

\section{Hasil Pengamatan Kepada Mitra}

Pada Tabel 1 merupakan proses dari pengamatan suhu ini dilakukan di 2 tempat yang berbeda mitra 1 terletak di Desa Bakalan, Kecamatan Bululawang, Kabupaten Malang yang mempunyai suhu $32^{\circ} \mathrm{C} / 21^{\circ} \mathrm{C}$ dan kelembapan $66 \%$ memiliki curah hujan hingga $80 \%$. Di mitra 1 terdapat ayam broiler yang berjumlah 24.000 dalam produksi telur ayam dapat memproduksi sekitar $8 \mathrm{Kw} /$ harinya. Lokasi mitra yang ke 2 terletak di Kecamatan Wagir, Kabupaten Malang yang memiliki suhu $32^{\circ} \mathrm{C} / 20^{\circ} \mathrm{C}$ dan kelembapan $68 \%$ memiliki curah hujan hingga $80 \%$. Dalam suhu dan kelembapan sangatlah berpengaruh dalam jumlah produksi yang terdapat pada peternakan ayam broiler, karena ayam broiler juga membutuhkan suhu yang hangat. Di sini terdapat jumlah ayam broiler sekitar 12.000 dalam produksinya ayam broiler dapat memproduksi $4 \mathrm{Kw} /$ harinya., jumlah ayam mati dalam perharinya mencapai 2-3/ hari. Umur ayam pada mitra 1 dipatok hingga 70 Minggu dan dalam mitra 2 diberi 106. 
Untuk makanan yang diberikan pada mitra 1 dan mitra 2 adalah kosentrat dan diberi minuman dari sumur bor. Dalam peternakan agar tidak mencapai kerugian harus menggunakan tanggal untuk setiap makanan, vitamin dan kosentrat yang akan diberikan pada ayam supaya dapat menurunkan angka kematian pada ayam, selain itu kebersihan kandang dan suhu dalam kandang juga sangat perlu diperhatikan, karena ayam broiler ini membutuhkan suhu yang hangat, jika saja suhu dan kelembapan tidak sesuai maka jumlah ayam meninggal akan semakin banyak akibatnya telur yang diproduksi juga akan semakin menurun.

Tabel 2. Hasil Tingkat Keadaan Mitra

\begin{tabular}{|c|c|c|c|c|c|c|}
\hline \multirow{2}{*}{ Jam } & \multicolumn{3}{|c|}{ Bululawang } & \multicolumn{3}{c|}{ Wagir } \\
\cline { 2 - 7 } & Suhu & Kelembapan & $\begin{array}{c}\text { Titik } \\
\text { Embun }\end{array}$ & Suhu & Kelembapan & $\begin{array}{c}\text { Titik } \\
\text { Embun }\end{array}$ \\
\hline 00:06:00 & $20^{\circ}$ & $83 \%$ & $23^{\circ}$ & $25^{\circ}$ & $79 \%$ & $21^{\circ}$ \\
\hline $00: 09: 00$ & $23^{\circ}$ & $85 \%$ & $25^{\circ}$ & $23^{\circ}$ & $80 \%$ & $25^{\circ}$ \\
\hline $00: 12: 00$ & $25^{\circ}$ & $93 \%$ & $22^{\circ}$ & $25^{\circ}$ & $88 \%$ & $24^{\circ}$ \\
\hline $00: 15: 00$ & $28^{\circ}$ & $80 \%$ & $23^{\circ}$ & $25^{\circ}$ & $73 \%$ & $21^{\circ}$ \\
\hline $00: 18: 00$ & $25^{\circ}$ & $85 \%$ & $25^{\circ}$ & $26^{\circ}$ & $75 \%$ & $25^{\circ}$ \\
\hline $00: 21: 00$ & $23^{\circ}$ & $85 \%$ & $22^{\circ}$ & $21^{\circ}$ & $85 \%$ & $23^{\circ}$ \\
\hline $00: 23: 00$ & $21^{\circ}$ & $88 \%$ & $23^{\circ}$ & $21^{\circ}$ & $77 \%$ & $21^{\circ}$ \\
\hline
\end{tabular}

Pada Tabel 2 menunjukkan tingkat keadaan kedua mitra, dimana dalam hal ini menggunakan proses 1 × 24 jam dalam setiap pemantauan yang telah dilakukan. Dalam hal ini menunjukkan mulai dari jam 6 pagi sampai dengan jam 11 malam memiliki suhu, kelembapan, dan titik embun yang berbeda-beda setiap 3 jamnya. Suhu menunjukkan panas dinginnya sebuah keadaan maupun benda, Kemudian kelembaban merupakan tingkat kebasahan sebuah udara yang dinyatakan dengan sebuah persentase. Kemudian titik embun merupakan suhu dimana udara yang harus didinginkan menjadi jenuh dengan uap air. Dari hasil bisa diketahui wilayah Bululawang condong dengan keadaan dingin namun di wilayah Wagir berbeda, diwilayah Wagir condong dengan keadaan yang panas. Dalam hal ini menunjukkan wilayah wagir yang memiliki potensi besar terhadap budidaya ayam jenis petelor. Serta dalam budidaya ayam jenis petelor juga harus memperhatikan setiap waktu, karena dalam waktu berbeda memiliki cuaca yang berbeda. Untuk itu diperlukan adanya perawatan dan pengecekkan setiap waktu di tempat budidaya ayam jenis petelor tersebut.

\section{DAMPAK DAN MANFAAT}

Kegiatan ini sangat bermanfaat bagi peternak ayam di wilayah Wagir. Adapun alat control yang dibuat adalah alat pengatur suhu dan kelembaban kandang guna meningkatkan kualitas dan jumlah telur ayam. Embrio ayam akan berkembang dengan baik, sehingga dapat menghasilkan anak ayam yang sehat.

Selain itu, adanya program pendampingan dan pelatihan untuk pengukuran suhu dan kelembaban, akan mendukung pemahaman peternak dalam mengoperasikan alat control tersebut. Pendampingan tersebut mampu membantu peternak telor (mitra) tentang cara untuk monitoring suhu dan kelembaban. Pelatihan juga dilakukan dalam rangka menambah pengetahuan dan skill peternak mengenai pentingnya pengaruh suhu dan kelembapan terhadap peternakan ayam petelor. Keterampilan tersebut diantaranya adalah penggunaan aplikasi pengukuran suhu dan kelembaban dengan smartphone bagi peternak. Kemudian dari pendampingan ini diharapkan dapat mengurangi resiko kematian terhadap ayam petelor. 


\section{KESIMPULAN}

Dalam pelaksanaan program pengabdian kepada masyarakat tahun 2019 ini berhasil menerapkan dan menggunakan aplikasi untuk mengukur suhu dan kelembaban kandang ayam petelor. Pelatihan dan penyuluhan yang telah dilakukan dapat meningkatan kemampuan dan keterampilan petelor dalam menggunakan aplikasi untuk mengukur suhu dan kelembaban. Dari kegiatan tersebut, peternak mampu mengurangi mengatur dan mengkondisikan suhu dan kelembaban agar tetap stabil sehingga resiko kematian pada ayam petelor menurun.

\section{REFERENSI}

Damayanti, P. (2019) 'Pemanfaatan Ekstrak Daun Afrika (Vernonia Amydalina) Terhadap Performa Broiler', Jurnal Agrisistem. 15(1), 23-28.

Fanani, Z. et al. (2019) 'Usaha Ternak Ayam Pedaging Sistem Kemitraan Pola Dagang Umum: Pemetaan Sumber Daya dan Model Pengembangan Broiler Livestock Business with General Trade Partnership System: Resources Mapping and Development Model', Sains Peternakan. 17(2), 5-11.

Fitriyani, F. dan Widyaningsih, I. U. (2018) 'Peternak Ayam Kampong Di Desa Panggungjati Kecamatan Taktakan Kota Serang Propinsi Banten', KAIBON ABHINAYA : Jurnal Pengabdian MAsyarakat, 1(1), 13-16.

Mappanganro, R., Syam, J. dan Ali, C. (2018) 'Tingkat Penerapan Biosekuriti Pada Peternakan Ayam Petelur Di Kecamatan Panca Rijang Kabupaten Sidrap', Jurnal Ilmu dan Industri Peternakan. 4(1), 354-370.

Pakaya, S. A., Zainudin, S. dan Dako, S. (2019) 'Performa Ayam Kampung Super Yang Di Beri Level Penambahan Tepung Kulit Kakao', Jambura Journal of Animal Science, $1(2), 40-45$.

Prastiyo, D. H., Hartono, D. I. P. dan H. Margianto, M. . (2018) 'Perencanaan Mesin Produksi Tepung Bulu Ayam Sebagai Campuran Pakan Ternak Unggas', Jurnal Teknik Mesin. 13(1). 1-5.

Ramdani, H. (2019) 'Pengelolaan Usaha Peternakan Melalui Manajemen Operasional Dan Feasibility Studi Sederhana Dan Modern', Jurnal ABM Mengabdi, 6(1), 1-7. 